\title{
A regional Alpine graphite décollement level beneath the NW Pannonian Basin
}

\author{
TARI, Gábor ${ }^{1}$, NÉMETH ,Viktória ${ }^{2}, \dagger$ HORVÁth, Frank $^{3}$, WeSZTERGOM, Viktor ${ }^{4}$ \\ ${ }^{1} \mathrm{OMV}$, Vienna, Austria \\ ${ }^{2}$ Geomega, Budapest, Hungary \\ ${ }^{3}$ Eötvös University, Budapest, Hungary, deceased \\ ${ }^{4}$ Széchenyi István Geophysical Observatory of the Hungarian Academy of Sciences, Sopron, Hungary
}

\section{Egy regionális alpi grafit lenyíródási felület a Pannon-medence ÉNy-i részén}

Összefoglalás

A Pannon-medence ÉNy-i részén található a több mint félévszázada kimutatott, ún. Dunántúli Vezetőképesség Anomália (TCA). Az anomália rendkívül alacsony ellenállású $(1-2 \Omega \mathrm{m})$, horizontálisan nagy kiterjedésú (néhány $1000 \mathrm{~km}^{2}$ ) és a felszín alatt, 3 és $15 \mathrm{~km}$ közötti mélységben fordul elő. Az anomália kialakulásának okairól és körülményeiről már többféle magyarázat született. Ezek az elméletek az alacsony ellenállást közel függőleges helyzetú dike-ok formájában jelentkező, grafittal vagy folyadékkal kitöltött törési zónákat vagy majdnem horizontális ausztroalpi takaróhatárokat feltételeztek. Eleddig a jól vezetó anomália analógiájára csak egyetlen kibukkanási helyet feltételeztek, a TCA-tól 300 km-re Ny-ra, a Drauzug-Gail-völgy térségében, a Keleti-Alpokban.

Korábbi munkák során is tettek már kísérletet a jól vezetô anomália és a 2D szeizmikus reflexiós szelvényeken nagy amplitúdóval jelentkező szeizmikus reflektorok korrelálására. Jelen cikk a 2D ipari szeizmikus szelvények felhasználásával történt szisztematikus korreláció eredményeit ismerteti. Az eredmények alapján az anomália felszín alatti kiterjedése és elhelyezkedése jól korrelál a kréta korú, közel horizontális helyzetú ausztroalpi takarós határokkal. Ezt a Dunántúliközéphegység és a Keleti-Alpok takarós egységeinek modern modellje is alátámasztja.

A felsô-ausztroalpi takaróegységek déli peremén, a Grauwacke-zónában számos felszíni grafitkibukkanás ismert. Az ÉNy-Stíria területén elhelyezkedő, oldalirányban nagy kiterjedésú grafitos egységek a karbon korú kőszén metamorfózisa során alakultak ki a krétában. Ebben a munkában elsőként dokumentálunk egy fúrást ÉNy-Magyarország területén ahol azonos korú grafitos egységet értek el. A magnetotellurikus anomália és a különleges szeizmikus szignál korrelációja alapján azonos paleozoos egységek a felsô-ausztroalpi takarórendszer alján, 3-15 km-es mélységben helyezkedhetnek el.

Mindezek alapján a TCA jelenlegi kiterjedésének és geometriájának legjobb magyarázata a grafit jelenléte a közel vízszintes helyzetú, tektonikusan kivékonyodott alpi nyírási felületek mentén a felső-ausztroalpi takarós egységek alsó határán.

Tárgyszavak: magnetotellurika, grafit, alpi, lenyíródás, Pannon-medence, Ausztria, Magyarország

Abstract

The so-called Transdanubian Conductivity Anomaly (TCA) of the Hungarian part of the NW Pannonian Basin has been well known for more than five decades. The exceptionally low resistivity (i.e. $1-2 \Omega \mathrm{m}$ ) zone has a very large areal extent (on the order a few thousand $\mathrm{km}^{2}$ ) and it is an entirely subsurface anomaly occurring at depth between circa $3-15$ $\mathrm{km}$, with no corresponding outcrops. Various geological explanations of this enigmatic crustal-scale geophysical anomaly range from invoking sub-horizontal Alpine nappe contacts to sub-vertical dikes with graphite and/or saline fluid content. Only one possible analogue outcrop area was considered for the high conductivity anomaly so far, namely the Drauzug/Gailtal area of the Eastern Alps in Austria, some $300 \mathrm{~km}$ to the West from the TCA area.

Previous attempts to find correspondence between the TCA and prominent seismic reflectors seen on 2D seismic reflection profiles were based on data acquired by research institutions. This study systematically correlates, for the first time, the TCA with 2D industry seismic reflection data in the same area. Our new results show a very strong correlation between the subsurface extent and location of the TCA with various sub-horizontally oriented Cretaceous Alpine nappe surfaces. In addition, we draw on the latest structural correlation of the Alpine nappe stack of the Transdanubian Range with its proper tectonic counterpart in the Eastern Alps.

At the southern edge of the Upper Austroalpine units in northern Styria, in the Veitsch Nappe of the Greywacke Zone, numerous graphite localities are known historically. These laterally extensive graphite units in NW Styria formed as the result of greenschist-grade metamorphism of a Carboniferous coal sequence during the Cretaceous. For the first time, we describe here one well penetration of possibly age-equivalent graphitic units in NW Hungary. Correlation of the magnetotelluric anomaly with the distinct reflection seismic signature suggests that the same Palaeozoic graphitebearing Upper Austroalpine units should be present at 3-15 km depth in our study area.

Therefore we propose that the best explanation for the observed extent and geometry of the TCA is the presence of graphite in subhorizontal, tectonically thinned detachment surfaces at the base of the Upper Austroalpine nappe edifice of NW Hungary. 


\section{Introduction}

The application of the magnetotelluric method, based on the early theoretical work of CAGNIARD (1953), has a long history in Hungary that dates back to the early 1960s (e.g. ÁDÁM \& VERÓ 1965). In particular, one of our co-authors, Prof. Ferenc (Frank) HoRvÁtH, whom this special issue is dedicated to, studied this field briefly during the early part of his academic career (e.g. ÁDÁM et al. 1970; STEGENA et al. 1971, 1972).

Due to the pioneering early studies using telluric (TT) and magnetotelluric (MT) measurements in Hungary, the Transdanubian Conductivity Anomaly (TCA) was first mentioned by ÁDÁM \& VERŐ (1965). The first evidence for a substantial subsurface anomaly was actually provided by the correlation of MT sounding results around Bakonybél with the signal registered at the Nagycenk geophysical observatory, some $100 \mathrm{~km}$ apart (Figure 1). At Bakonybél, the long-period changes were missing due to the very low crustal resistivity, therefore the pronounced amplitude decrease was attributed to a high conductivity anomaly beneath the Transdanubian Range of NW Hungary. In the following years the outline of the TCA was systematically mapped using relative telluric frequency soundings (ÁDÁM \& VERÓ 1965). Based on the characteristics of the relative telluric frequency curves, it became clear that the high conductivity formations are located beneath the thick Mesozoic carbonates, possibly within the Palaeozoic sequence. The first MT soundings in the Bakony Mts. were done in 1966 and these measurements confirmed the earlier results based on relative telluric frequency soundings (TAKÁCs 1968).

From the 1970s on, there were two institutions, which were conducting MT measurements in NW Hungary. The Eötvös Loránd Geophysical Institution (ELGI) was focusing on regional transects making about 200 measurements in the 0.05-1000 s period range (e.g. NEMESI et al. 1994). The distance between individual measurement points was on average $2-2.5 \mathrm{~km}$. In contrast, the MTA Geodetic and

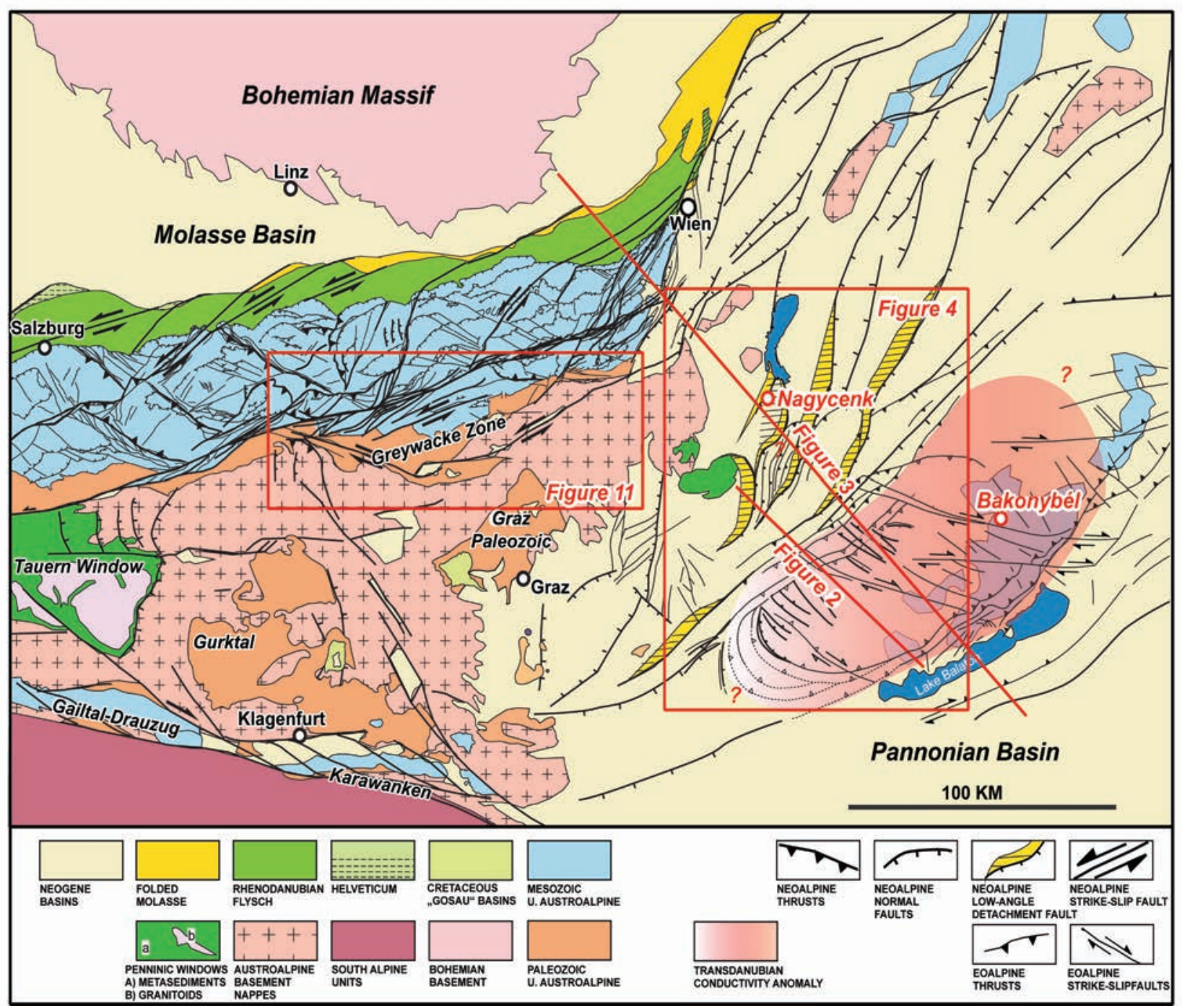

Figure 1. Alpine structural elements of the Eastern Alps and the western Pannonian Basin, modified from LINZER \& TARI (2012). Geographic locations mentioned in the text are highlighted by red dots. The area of the TCA in NW Hungary is highlighted by a semitransparent polygon

1. ábra. A Keleti-Alpok és a Pannon-medence nyugati részének szerkezeti képe, LINZER \& TARI (2012) után módosítva. Az anomália (TCA) területét az átlátszó piros poligon jelöli 
Geophysical Research Institute of the Hungarian Academy of Sciences (GGKI) had MT measurements in the 10-3600 s period domain, at about 100 locations. Despite the differences, the two data sets are complementary in the context of assessing the TCA (ÁDÁm 2001).

As to the geologic nature of the TCA, various interpretations were proposed during the last three decades. An early interpretation by ÁDÁM (1976) considered fracture zones with electrolites which could have very high conductivity given the expected temperature range at depth. A subsequent interpretation considered vertical to near-vertical dikes or sets of dikes as the cause of the TCA (ÁDÁm 1987, 1996). Since a widely accepted regional tectonic model in the 1980s proposed a westward correlation of the Bakony Mts. to the West to the Drauzug Mts. in Austria (KÁZMÉR \& KovÁCS 1985), additional MT measurements were made in the Gail Valley and in the Karawanken Mts. in Austria (ÁDÁM et al. 1990). These MT measurements indicated that a graphite sequence of Palaeozoic age, located beneath Mesozoic carbonates, is probably responsible for the MT signal, which was found to be very similar to that of the TCA (ÁDÁm et al. 1990).

In this work, we consider the TCA as the result of deeply buried sub-horizontal Carboniferous graphite layers, which formed Eoalpine (Cretaceous) décollement levels providing the overthrust planes of Alpine nappe structures those. According to our interpretation, the best analogues for these graphitic units are located along the eastern Greywacke Zone in the Eastern Alps. These laterally extensive and well studied graphite units between Lassing and Kohlbachgraben (Styria) formed as the result of greenschist-grade metamorphism of a Carboniferous coal sequence during Cretaceous nappe stacking of the Alps (e.g. NEUBAUER et al. 1994).

\section{Geological setting}

Building on the interpretations of HORVÁTH \& RUMPLER (1984), HoRVÁTH et al. (1987), HoRVÁtH (1993), TARI (1994, 1996), TARI \& HORVÁTH (2006) and HORVÁTH et al (2006), an overview was published on the Alpine nappe structure of the Transdanubian Range by TARI \& HORVÁTH (2010). Note that Alpine nappe structure of the Transdanubian Range has been debated for about a century in the Hungarian geologic literature (see HoRvátH \& DOMBRÁdi 2010, for a discussion). More regional overviews (e.g. SCHMID et al. 2008, Frotzheim et al. 2008) also described the Transdanubian Range as a correlative Alpine unit to the Drauzug (Figure 1). More specifically, the Drauzug-Gurktal nappe system of SCHMID et al. (2004) represents a nappe stack originally located south of the Meliata embayment and in their synthesis the Palaeozoic of the Transdanubian Range correlates with the Graz Palaeozoic (Figure 1). The Greywacke Zone forms the stratigraphic basis of a part of the Northern Calcareous Alps (Figure 1) and finds its eastern continuation in the Gemmericum of the West Carpathians (SCHMID et al. 2004, 2008).

Another point of view was introduced by TARI \& HORVÁTH (2006) and shortly after by LINZER \& TARI (2012) emphasising the structural similarities between the Northern Calcareous Alps and that of the Transdanubian Range situated in the highest structural position within the Alpine nappe stack. In our view, the Upper Austroalpine units, such as the Drauzug-Gurktal nappes, the Palaeozoic of Graz (Figure 1) and various Palaeozoic units in the subsurface of the Styrian and Danube Basin are distributed as large klippen in the central and southern areas of the Eastern Alps corresponding to a once-contiguous Upper Austroalpine nappe system covering the entire realm (TARI 1994).

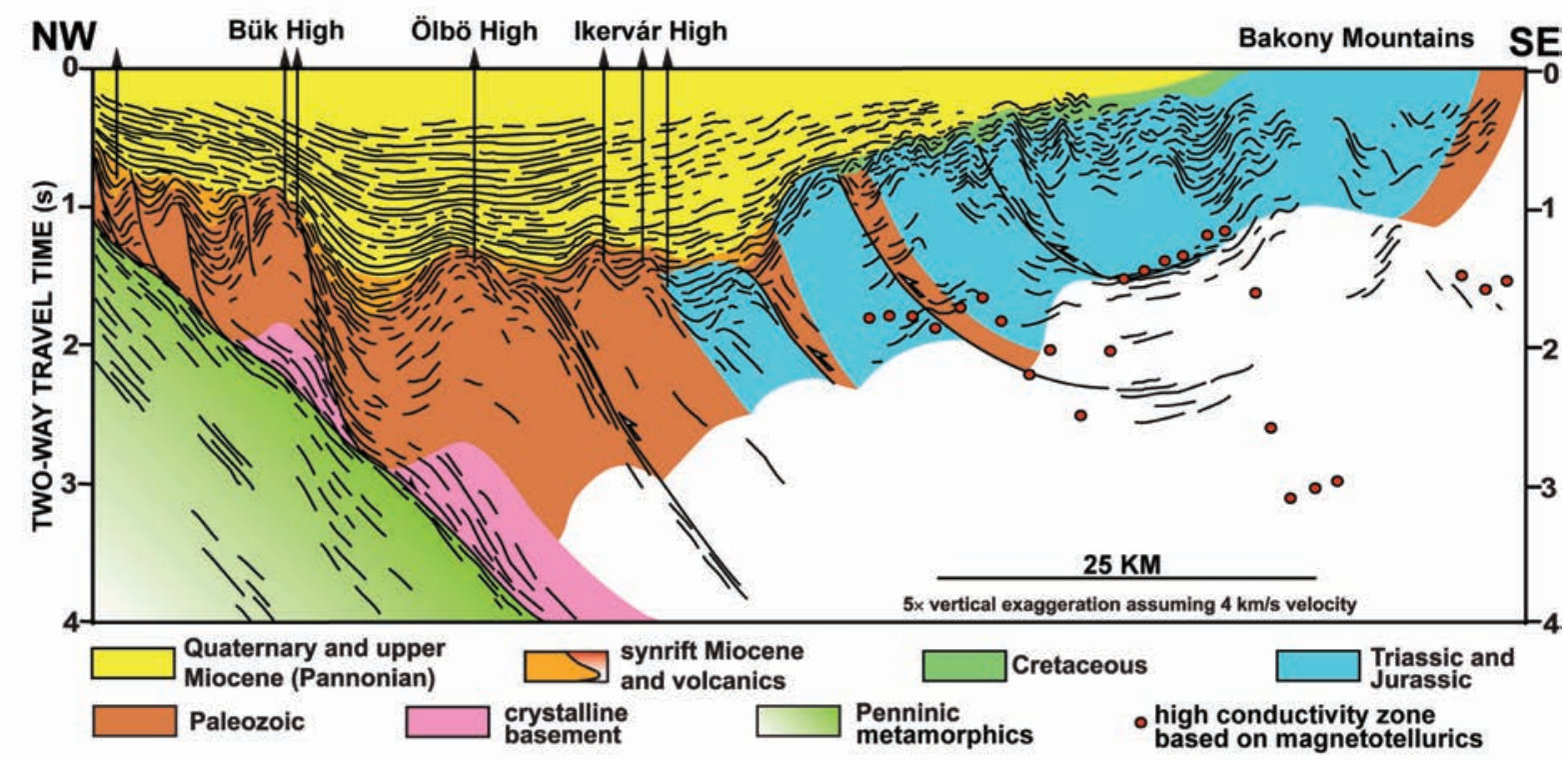

Figure 2. Line drawing interpretation of a regional transect based on vintage 2D reflection seismic data in north-western Hungary (for location see Figure 1), adapted from TARI \& HORVÁTH (2006)

2. ábra. Regionális geológiai szelvény értelmezése $2 D$ szeizmikus reflexiós mérések alapján (TARI \& HoRVÁTH, 2006). A szelvény nyomvonalát az 1. ábra mutatja 


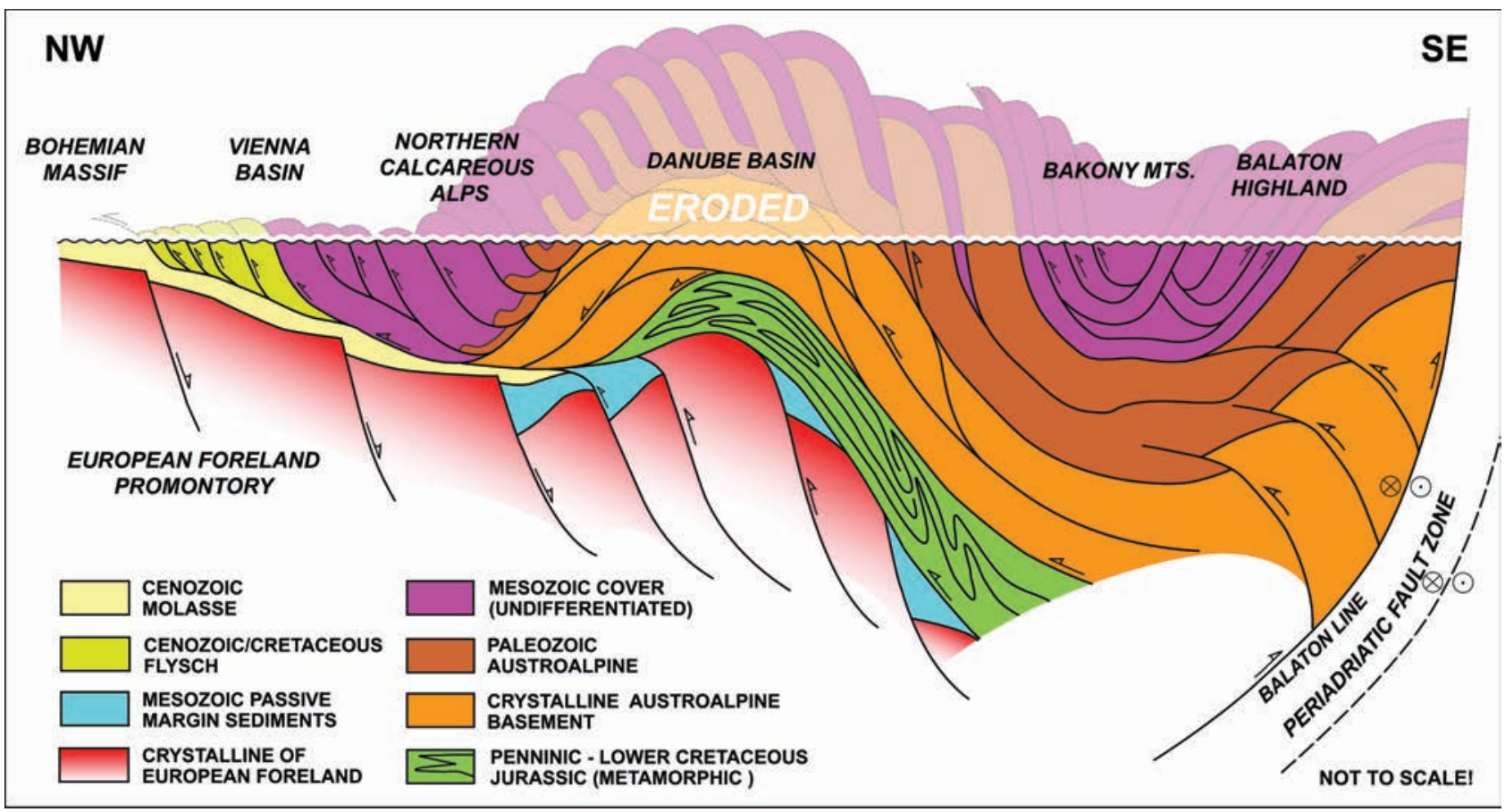

Figure 3. Idealised cross section across the Alpine-Pannonian junction area (for location see Figure 1) modified from TARI \& HoRVÁTH (2006). Note that the flattening datum level of this cartoonish transect is the erosional surface at the base of the combined Senonian-Cenozoic basin fill. See text for detailed explanation 3. ábra. Idealizált szerkezeti modell a Keleti-Alpok Pannon-medencével határos területén keresztül (nyomvonalát lásd. az 1. ábrán), TARI \& HORVÁTH (2006) után módositva. A szerkezeti modell referencia szintje a senon-kainozoos medencefeltöltödés bázisának eróziós felszíne. Ennek részletes magyarázatát lásd a szövegben

To illustrate the presence of Eoalpine (Cretaceous) nappe systems beneath the NW Pannonian Basin, to be correlated with the classical units of the Eastern Alps (Figure 1), a simplified regional composite seismic transect is shown here (Figure 2) adapted from TARI \& HORVÁTH (2006). This regional transect has been reproduced as a line drawing interpretation for clarity, trending generally northwest-north-north-west, therefore as a dip line with respect to most Eoalpine and Neoalpine structures in NW Hungary. Note that some of the MT measurement points of the TCA have been projected onto this regional section (Figure 2) suggesting some broad coincidence of the high conductivity anomalies with the inferred nappe boundaries to be described in this work.

To better understand the pre-existing Eoalpine nappe structure, the footprint of the Neogene extensional tectonics needs to be removed followed by the various Palaeogene and Senonian basin fragments. The idealised cartoonish transect across the Alpine-Pannonian junction area based on a regional transect by TARI (1996) is a qualitative attempt to illustrate the interpretation concept that the Eoalpine nappe units of the Eastern Alps were once contiguous with those of the Transdanubian Range (Figure 3). In particular, both the Northern Calcareous Alps including the Greywacke Zone at its base and the nappe system of the Bakony Mountains have an Upper Austroalpine tectonic position, i.e. on top of the Alpine nappe system. This once continuous nappe stack disintegrated because of large-scale exhumation and erosion during the late Oligocene and the subsequent Miocene extensional periods (e.g. HoRváth et al. 2006, TARI \& HoRVÁTH 2006, KUHLEMANN et al. 2006).

The important aspect of the cartoon model (Figure 3) for this work is that the area where the TCA is located have Upper Austroalpine Palaeozoic units which do have counterparts in the outcrops in the Eastern Alps along strike (i.e. in the Gurktal and Graz Palaeozoic of the DrauzugGurktal nappe system and the Greywacke Zone) and some limited outcrops along the Balaton Highland (Figure 1). Unfortunately, the subcrop of the Upper Austroalpine Palaeozoic units beneath the Neogene to Quaternary Danube Basin in the area of the TCA is located entirely in the subsurface and, therefore, is known only from wells (e.g. HAAS et al. 2010). However, it is important to note that BALÁzs (1971, 1975) has already correlated the various poorly dated Palaeozoic units encountered in numerous hydrocarbon exploration wells with those of the Graz Palaeozoic, based on their lithological characters.

\section{Data base and methods}

The NW Pannonian Basin of Hungary is well covered by an extensive 2D seismic reflection data set (Figure 4), which was mostly acquired in the 1980s (e.g. TARI 1994, TARI \& HORVÁtH 2010). These are migrated standard industry seismic profiles processed typically down to $4 \mathrm{~s}$ two-way travel time. Whereas there are some recently acquired 3D seismic reflection data sets in the same area, we 


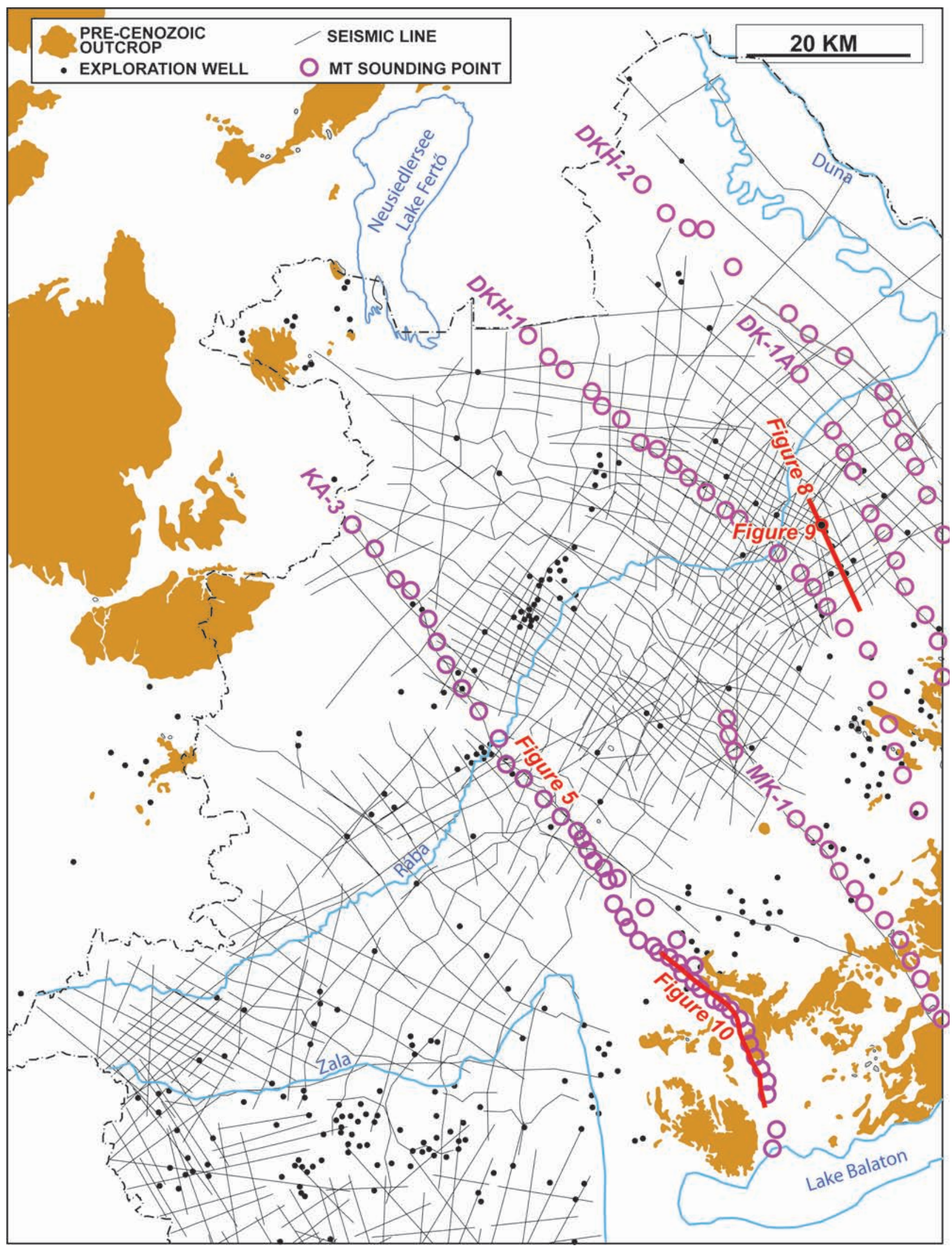

Figure 4. Data base for this study: 2D seismic reflection (black lines) and MT (magnetotelluric) sounding points (magenta circles) in the NW Pannonian Basin of Hungary (for a location see Figure 1)

4. ábra. A vizsgálat során felhasznált adatok helyszínrajza: 2D szeizmikus reflexiós szelvények (narancssárga vonalak)és MT (magnetotellurikus) szondázási pontok (lila körök) a Pannon-medence ÉNy-i részén. A vizsgált terület az l. ábrán látható 
Table I. Resistivity measurements on graphite samples from the Eastern Alps I. táblázat. Ellenállás mérési eredmények grafit mintákon a Keleti Alpokból

Pure graphite from Kaisersberg, Styria

(Note that the bedding was difficult to define in this sample)

a) $\rho^{\mathrm{II}}=0.0315 \Omega \mathrm{m} \quad \rho^{\mathrm{\alpha}}=0.267 \Omega \mathrm{m}$ anisotropy: 9.7

b) $\rho^{\mathrm{II}}=0.0307 \Omega \mathrm{m} \quad \rho^{\mathrm{L}}=0.44 \Omega \mathrm{m} \quad$ anisotropy: 14.6

Massive, but laminated graphite from Hochfilzen, Tirol
a) $\rho^{I I}=14.9 \Omega \mathrm{m}$
$\rho^{\prime}=72 \Omega \mathrm{m}$
b) $\rho^{I I}=12 \Omega \mathrm{m}$
$\rho^{\prime}=93 \Omega \mathrm{m}$
anisotropy: 4.8
anisotropy: 7.78

have not integrated those into our study. We had also access to about 200 hydrocarbon exploration wells drilled in the area (Figure 4), including well-logs, cutting and core descriptions and final geological well reports. Since most of these wells were drilled in the 1970s and 1980s, the well log suites typically do not include velocity (i.e. sonic) information which made the proper depth conversion on the wells challenging. Since all the reflection seismic data was interpreted in the two-way travel time domain, the depth conversion was critical to plot the position of the highconductivity anomaly on the seismic profiles (i.e. Figures 2 , and later 8,9). The depth conversion was based on regional time-depth functions derived from 8 well check-shot surveys in the Hungarian Danube Basin (NÉMETH 2014).

The numerous MT (magnetotelluric) sounding points in the same general area (Figure 4) were compiled from various sources, including NEMES et al. (1994), ÁDÁm (2001) and NÉMETH et al. (2014). The details of the raw MT data, processing schemes, also including inversion, were described by NÉMETH (2014). 74 individual MT sounding points were processed using the GEOSYSTEM WinGLink software. This software offers two 1D inversion algorithms, using the Bostick transformation or the Occam inversion (BOSTICK 1977, ConstaBle et al. 1987). The 1D inversion was done on MT stations measured along two regional transects (KA-3 and DHK-1) measured by the Eötvös Loránd Geophysical Institution. Whereas the KA-3 transect is about $95 \mathrm{~km}$ long with $49 \mathrm{MT}$ sounding points, the DKH-1 transect is about 80 km long with 25 MT stations (Figure 4).

To constrain the modelling results assuming graphitic lithologies as the primary cause for the TCA, we also measured graphite rock samples from outcrops and mines located in the Greywacke Zone of the Eastern Alps (Table I).

\section{Inversion and interpretation of the magnetotelluric data sets in the context of the TCA}

The magnetotelluric inversion results along the longer and better constrained KA-3 transect are reproduced here (Figure 5), adapted from NÉMETH et al. (2014). On the SE part of this regional MT transect, beneath the Bakony Mts., the TCA manifests itself by two exceptionally high conductivity zones (coloured in red) found at upper crustal depth $(3-15 \mathrm{~km})$. The overall position of this "double-decker" anomaly coincides with the primary synform of the Transdanubian Range. The thick Triassic to Jurassic carbonates (up to 2-3 km) outcropping on the surface have a distinct high resisitivity signal with values in the 200-1000 $\Omega \mathrm{m}$ range. Between about KA-3-17 and KA-3-18b this succession is repeated by overthrusting (e.g. TARI \& HORVÁTH

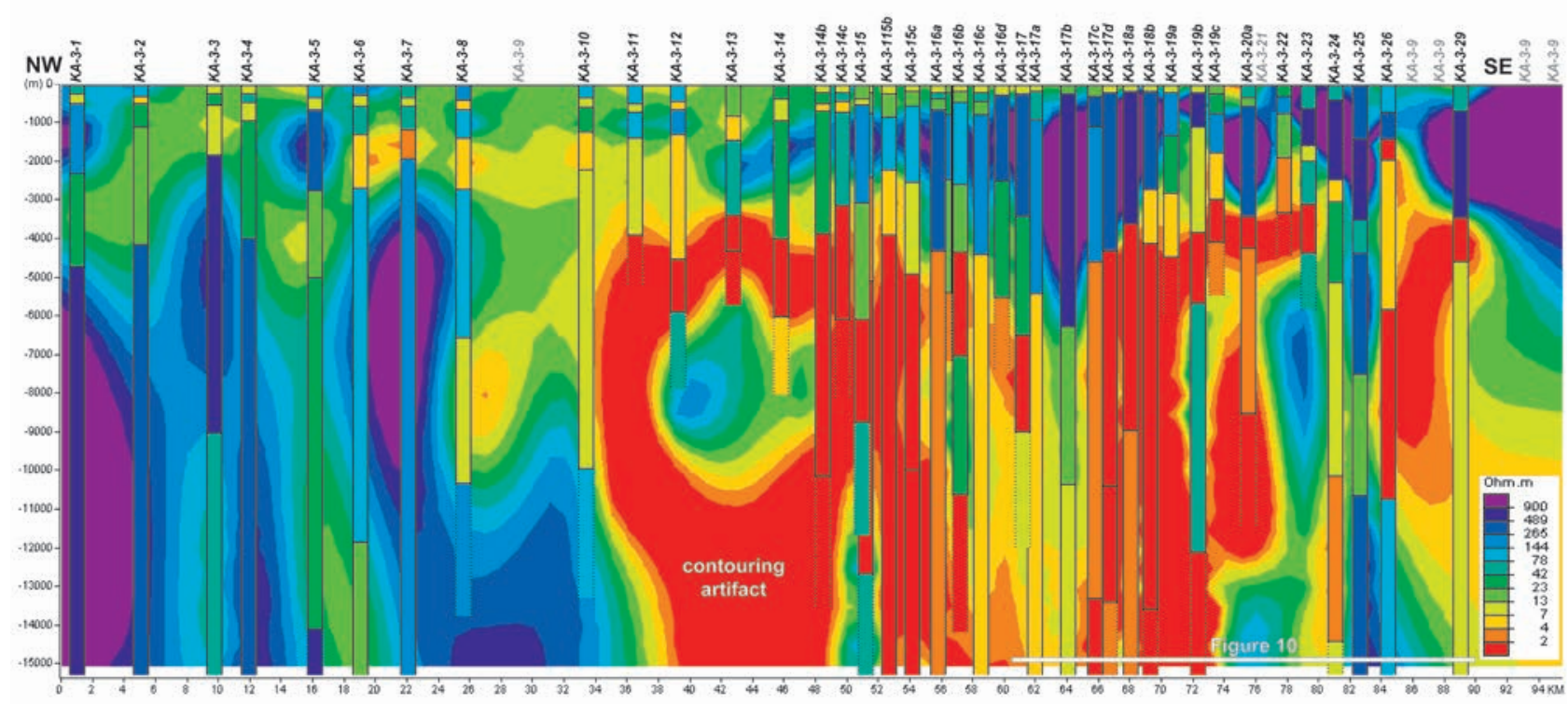

Figure 5. Regional MT transect (KA-3) across the NW Pannonian Basin, Hungary showing the presence of exceptionally high conductivity zones (coloured in red) at upper crustal depth (3-15 km). For location see Figure 4. Note that there are at least two of these MT anomalies, a shallower one and a deeper one, corresponding to two interpreted Eoalpine detachment levels. Note that the "ring-shaped" anomaly in the center is a contouring artifact. Vertical exaggeration is 2.5

5. ábra. Regionális MT szelvény (KA-3) a Pannon-medence ÉNy-i részén, amelyen a rendkívül magas ellenállású zónák (piros színnel jelölve) a felsö kéregben láthatóak, 3-15 km mélységben. A szelvény elhelyezkedését a 4. ábra mutatja. A szelvényen két MT anomália azonositható, egy sekélyebb és egy mélyebb, melyek megfeleltethetök egy-egy eoalpi lenyíródási felületnek. Megjegyzendő, hogy a szelvény közepén található „gyürü alakú” anomália a kontúrozás hibájából adódik, az értelmezés során figyelmen kívül kell hagyni. Vertikális túlmagasitás: 2,5 
2010) and that is why the total thickness of the Lower Mesozoic carbonates is about $5 \mathrm{~km}$ in the center of the Bakony syncline (Figure 5). Note that the deep "ring-shaped" low-resistivity anomaly between KA-3-11 and KA-315 is a contouring artifact and it should be ignored. Similarly, another contouring artifact is the one at the south-eastern end of the transect where a deeper and relatively steeply dipping segment of the TCA, which could be followed through the MT stations KA-3-24, -26 and -29, probably projects up closer to the surface near the Lake Balaton.

Importantly, the TCA, defined by low resistivity anomalies in the 2-4 $\Omega \mathrm{m}$ range, cannot be found to the NW from the MT station KA-3-11 (Figure 5). This marked change in the MT resistivity response can be confidently followed along strike in a NE-SW direction as the map-view results of NEMES et al. (1994) showed. This marked change defines the extent of the TCA to the NW (Figure 1).

Considering the various explanations for the extremely low resistivity anomaly (e.g. ÁDÁM 1980, 1987, 1996), we prefer the model whereas graphite is the primary cause (ÁDÁM 1996, GLOVER \& ÁDÁM 2008), for geological reasons (see later). Assuming graphitic lithologies, the question arises how much graphite is required to cause the observed average horizontal conductivity of about 1-2 $\Omega \mathrm{m}$ ? We have built geologically reasonable models for a $100 \mathrm{~m}$ thick gross lithologic column with variable amount of graphite and other common lithologies, such as shale, silt, sandstone and limestone (Figure 6). The $100 \mathrm{~m}$ thickness has been chosen as it is a vertical interval which is still resolvable by both MT sounding and conventional industry reflection seismic data at the depth of 4-8 km. Whereas the typical resistivities for the non-graphitic lithologies in these lithologic columns (Figure 6) were selected based on published literature (e.g. KELLER 1987), we have actually measured the resistivity of a graphite rock sample from the active Kaisersberg graphite mine (Table I).

We chose to have various amounts of net graphite emplaced within the $100 \mathrm{~m}$ lithologic column, i.e. 1, 2, 5 and $10 \mathrm{~m}$ thick layers (Figure 6). The calculations for the average horizontal resistivity then produced $3.01,1.52,0.62$ and $0.31 \Omega \mathrm{m}$ for these cases, respectively (Figure 6). Therefore the modelling showed that just a few metres thick graphite layer could cause the typically observed $1-2 \Omega m$ resistivity of the Transdanubian Conductivity Anomaly (TCA) of the Hungarian part of the NW Pannonian Basin.

\section{Correlation of the high-conductivity zone with prominent seismic reflectors}

Many seismic examples compiled by NÉMETH (2014) show that the TCA does correspond in many instances to a distinct reflector package on seismic reflection profiles. For brevity, here only two of these seismic lines will be
MODEL 1

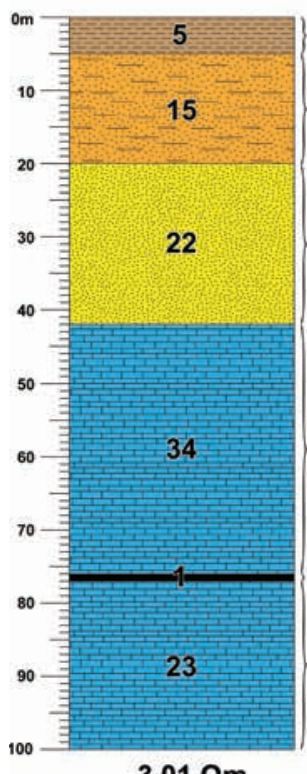

$3.01 \Omega m$
MODEL 2

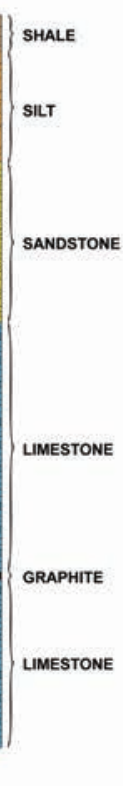

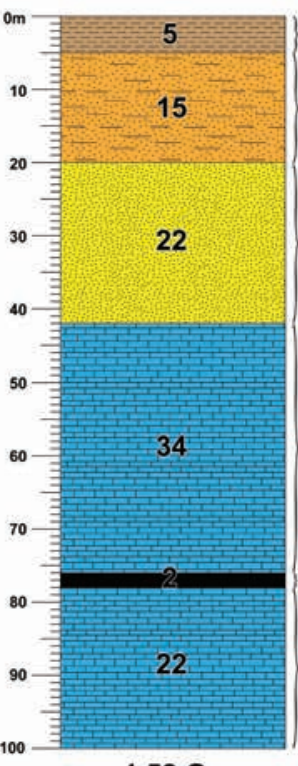

$1.52 \Omega m$
MODEL 3

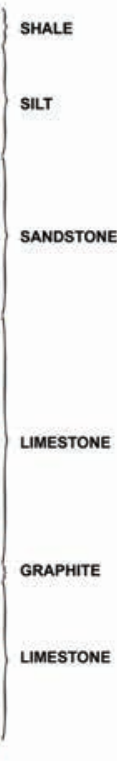

Figure 6. For modelling the impact of graphite thickness on the MT anomaly, we chose to have various amount of net graphite within a $100 \mathrm{~m}$ lithologic column, i.e. $1,2,5$ and $10 \mathrm{~m}$ thick layers. The calculations for the average horizontal resistivity then produced $3.01,1.52,0.62$ and $0.31 \Omega \mathrm{m}$ for these cases, respectively. Assuming a $100 \mathrm{~m}$ gross lithologic interval resolvable by conventional industry reflection seismic data at the depth of $5-10 \mathrm{~km}$, we found that just a few metres of net graphite lithology could reproduce the observed average horizontal conductivity of about (i.e. 1-2 $\Omega \mathrm{m}$ ) of the Transdanubian Conductivity Anomaly (TCA) in the NW Pannonian Basin

6. ábra. Különbözö vastagságú grafitrétegek alacsony ellenállás anomáliát okozó hatásának modellezése. A rendelkezésünkre álló kaisersbergi mintákból a grafit ellenállása ismert (I. táblázat), a különbözól litológiákra pedig becsülhetö, így egy 100 m vastagságú rétegsor átlagos ellenállásértéke meghatározható. A rétegsor felépitése szintén megadható ipari reflexiós szeizmikus adatok segitségével 5 -10 km mélységben. A modellezés alapján már néhány m vastagságú grafitréteg is okozhat hasonlóan alacsony horizontális irányú vezetöképesség anomáliát (1-2 $\Omega \mathrm{m})$, mint amilyen a Dunántúli Vezetöképesség Anomália (TCA) esetében is megfigyelhetỏ a Pannonmedence ÉNy-i részén 


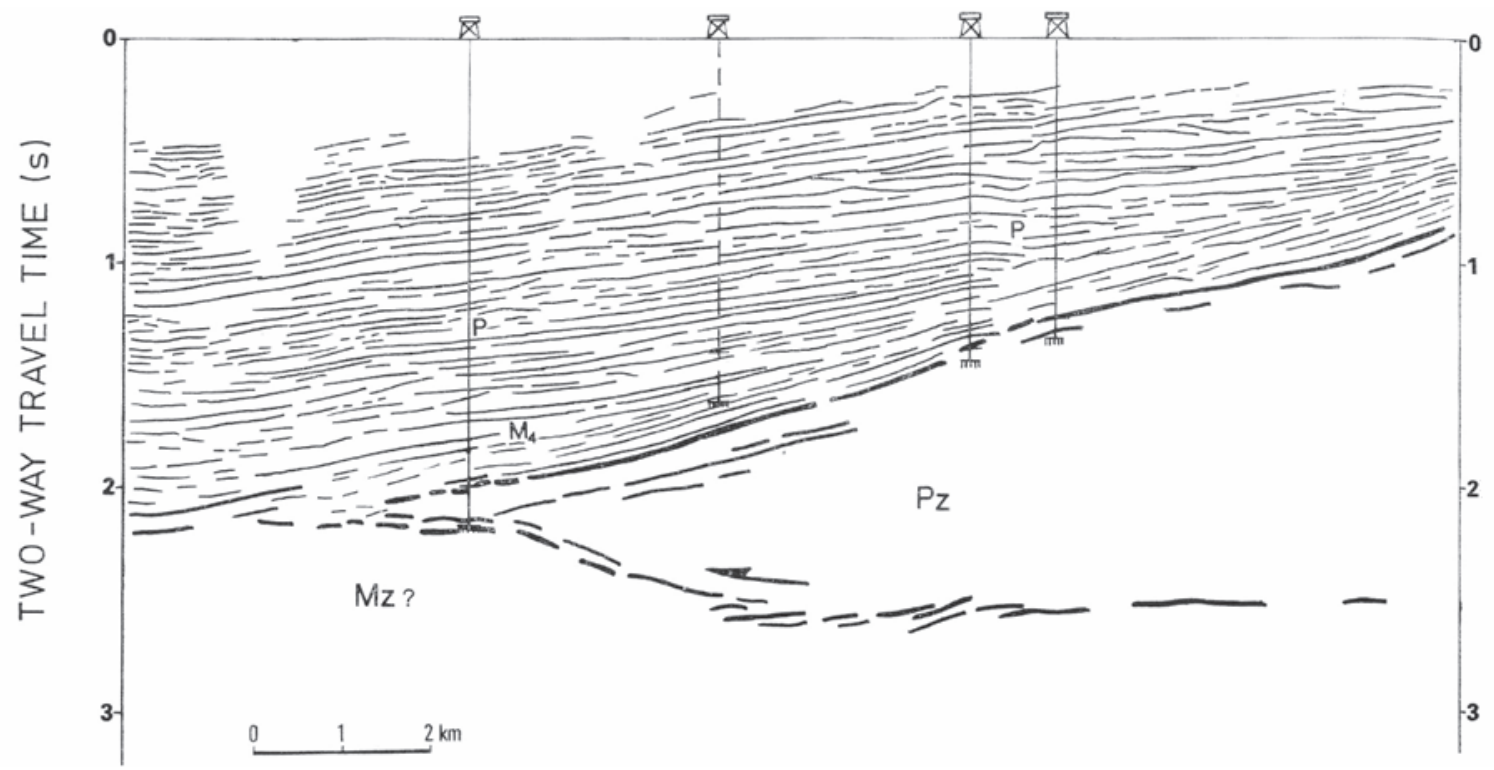

Figure 7. Interpretation of a vintage industry 2D reflection seismic line (Vpá-10) adapted from HoRVÁtH \& RuMPLER (1984). The prominent strong package of reflectors beneath within the pre-Cenozoic basement was interpreted here, for the first time, as the seismic expression of a Alpine (Cretaceous) nappe boundary (for location see Figure 4)

7. ábra. 2D szeizmikus reflexiós szelvény (Vpá-10) értelmezése HORVÁTH \& RUMPLER (1984) szerint, amelyen elöször kötötték a prekainozoos aljzatban jelentkezö erös reflexiókat kréta korú alpi takaró határához (a szelvény nyomvonalát lásd a 4. ábrán)

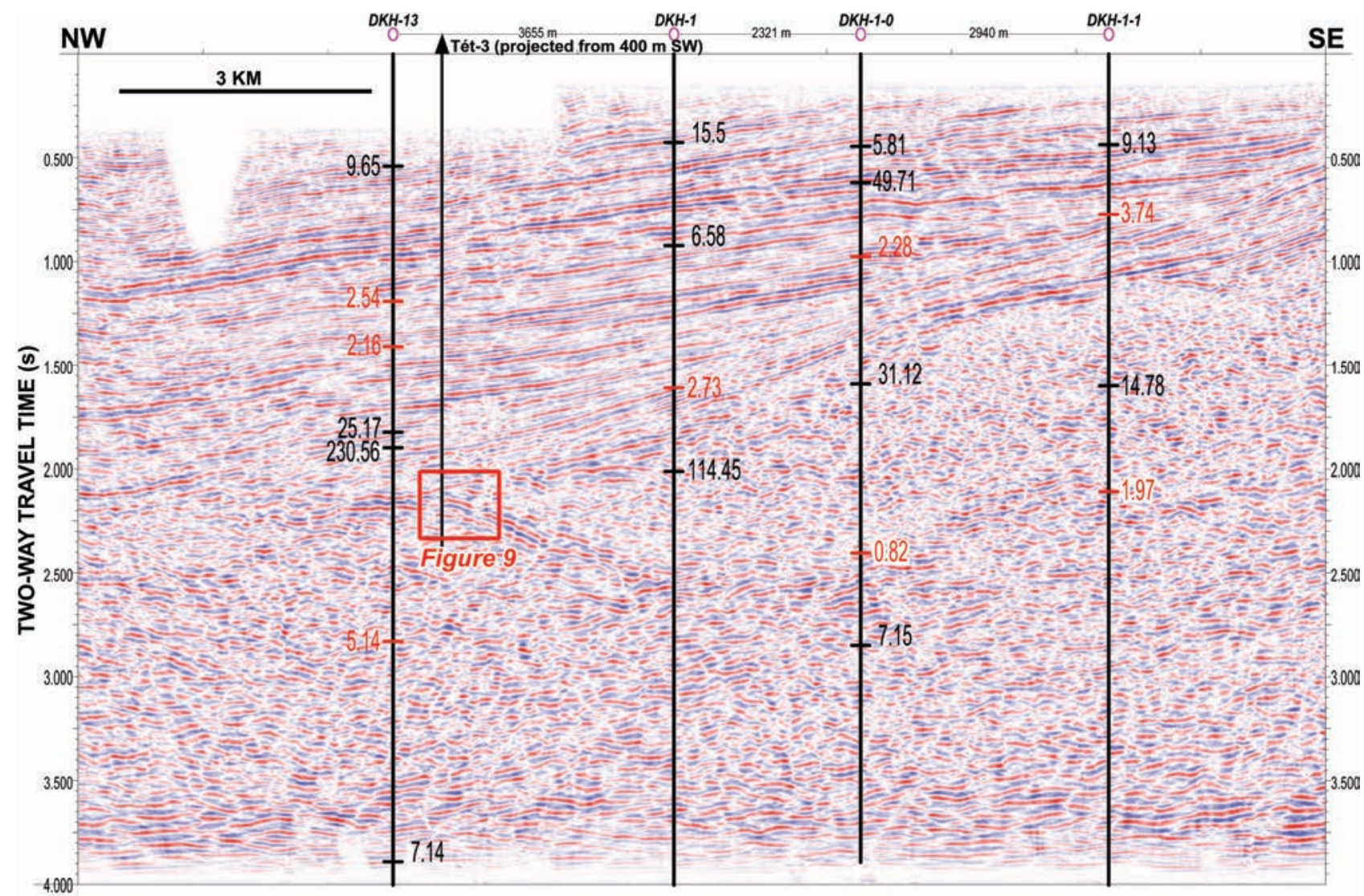

Figure 8. The same seismic section (Vpá-10) as shown in Figure 7, but here the MT inversion results were plotted on the line, modified from NÉMETH (2014). Low resistivity values are highlighted in red. Note the coincidence of the prominent package of reflectors inferred to be an Alpine detachment surface by HoRvÁTH \& RUMPLER (1984) with two very low resistivity measurements (i.e. 0.86 and $1.97 \Omega \mathrm{m}$ ) corresponding to the TCA (for location see Figure 4)

8. ábra. A Vpá-10 szeizmikus szelvény, raita az MT inverzió eredményeivel, módosítva NÉMETH (2014) után. Az alacsony ellenállásokat a piros értékek jelölik. Megfigyelhetö, hogy a HoRVÁTH \& RUMPLER (1984) által alpi lenyíródási felületként értelmezett reflexió jól egybeesik két alacsony ellenállású zónával (0.86 és 1.97 Sm), melyek megfeleltethetők a vezetöképesség anomáliának (TCA, a szelvény nyomvonalát lásd a 4. ábrán) 
reproduced and discussed. In particular, we chose a vintage industry 2D reflection seismic line (Vpá-10) which turned out to be crucially important for HORVÁTH \& RUMPLER (1984) to suggest for the first time that the prominent strong package of reflectors beneath within the pre-Cenozoic basement is the seismic expression of a Cretaceous Alpine nappe boundary (Figure 7). Along this seismic section, the lithology of the pre-Cenozoic basement is constrained by hydrocarbon exploration wells. Moreover, the well (Tét-3) on the NW end of the section was drilled specifically to penetrate the inferred Alpine overthrust interpreted to be located between Palaeozoic units on top and Mesozoic units below (HORVÁTH \& RUMPLER 1984). According to HoRvÁTH \& RUMPLER (1984), this well did not reach the expected overthrust plane because the drilling operations became difficult and the well was terminated some $400 \mathrm{~m}$ short of the original total depth. The well encountered about $400 \mathrm{~m}$ slightly metamorphosed Palaeozoic units in the pre-Cenozoic basement before reaching the TD.

The same seismic section (Vpá-10) was re-examined by NÉMETH (2014). The nearby MT inversion results were projected and plotted on the line which is displayed in two-way travel time, using the regional time-depth conversion based on nearby well check shots (Figure 8). Low resistivity values (i.e.

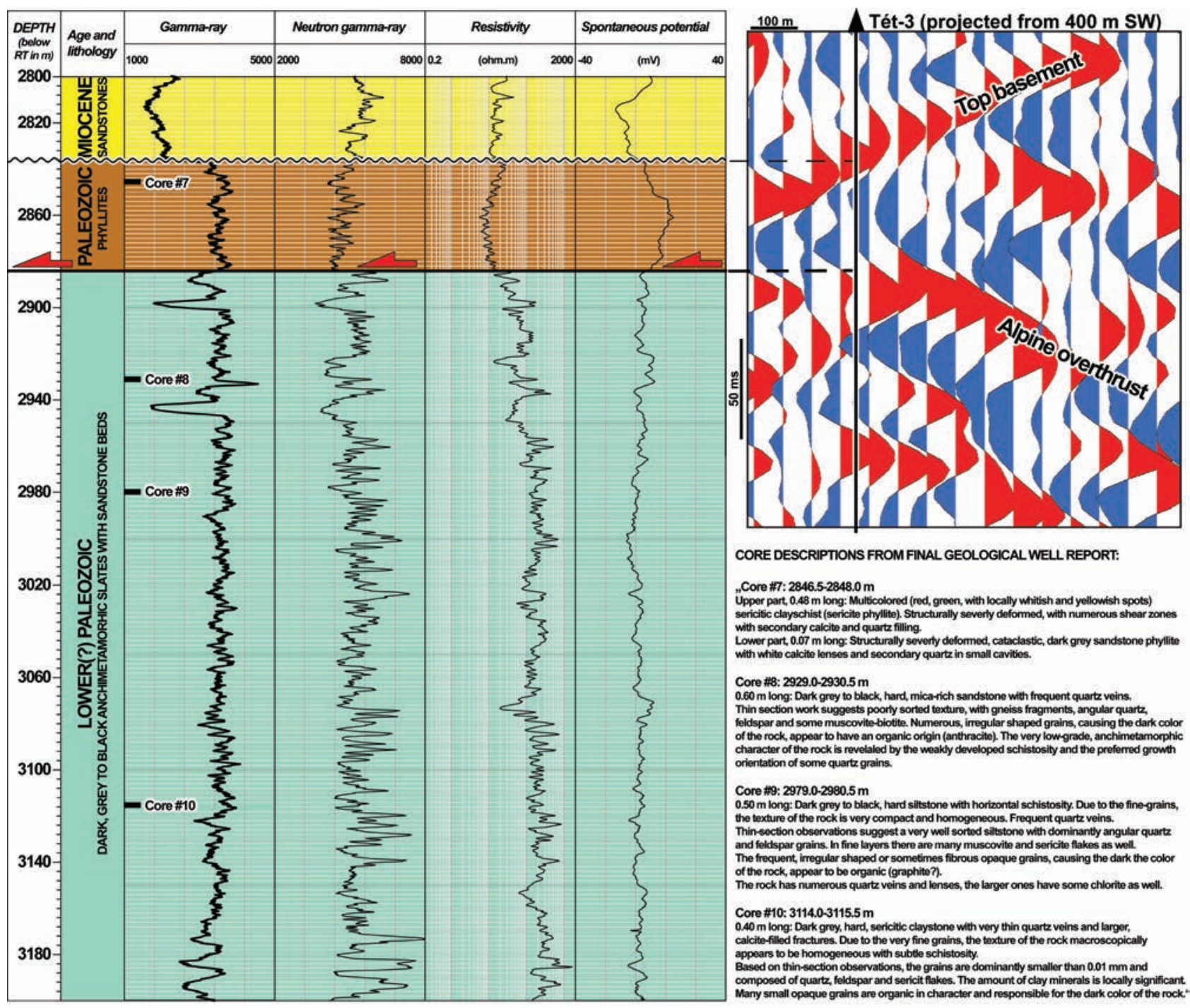

Figure 9. Well-logs of the Tét-3 well displayed between 2800-3200 m. Note the marked character change on the resistivity log at $2882 \mathrm{~m}$ depth, subdividing the Palaeozoic sequence into two parts. The core descriptions reproduced from the final geologic report without any changes also support the topmost $50 \mathrm{~m}$ of this sequence being low-grade (epimetamorphic) metamorphosed phyllites as opposed to the underlying anchimetamorhic sandy slates. A zoomed-in part of the Vpá10 migrated time seismic section (Figure 8) is displayed assuming a $3000 \mathrm{~m} / \mathrm{s}$ average seismic velocity in the vicinity of the overthrust plane. Note that this assumption has been made due to the lack of a proper synthetic seismic tie. Red and blue wiggles stand for seismic peaks and troughs, respectively. The seismic traces diplayed are about $60 \mathrm{~m}$ apart and the well has been projected into the plane of the seismic section by about $400 \mathrm{~m}$ from the SW

9. ábra. Karotázs szelvény a Tét-3 fúrásból 2800-3200 m közötti mélységben. Különösen az ellenállás szelvényen $2882 \mathrm{~m}$ mélységben figyelhetö meg egy markáns változás, amely a paleozoos rétegsort két részre bontja. A magleírás szintén alátámasztja ezt, a rétegsor legfelsö 50 méterét alacsony metamorffokú (epimetamorf) fillitek alkotják, szemben az alatta lévő anchimetamorf homokos palákkal. Az ábra jobb oldalán a Vpá-10 (8. ábra) migrált idöszelvény egy kinagyított része látható, $3000 \mathrm{~m} / \mathrm{s}$ átlagos szeizmikus sebességet feltételezve az áttolódási sík környezetében. Megfelelö szintetikus szeizmogramm hiányában a sebesség értéke csak egy becsült érték. A piros és kék amplitudók a szeizmikus csúcsokat és völgyeket jelölik. Az egyes szeizmikus csatornák távolsága kb. $60 \mathrm{~m}$, míg a kút kb. $400 \mathrm{~m}$ távolságból vetül a szeizmikus szelvényre DNy-i irányból 
less than $5 \Omega \mathrm{m}$ ) are shown in red. Note the coincidence of the prominent package of intra-basement strong reflectors inferred to be an Alpine detachment surface by HoRváTH \& RUMPLER (1984), with two very low resistivity measurements (i.e. 0.86 and $1.97 \Omega \mathrm{m}$ ) corresponding to the TCA (NÉMETH 2014).

The final geological well report on this particular well was finished in November 1985, obviously not available to HORVÁTH \& RUMPLER (1984) at the time of writing their paper. However, in the report we have found evidence for the presence of a) an Eoalpine overthrust plane penetrated in the well and b) possibly graphite based on the conventional cores taken in the poorly dated Palaeozoic sequence in this well (Figure 9). Between 2822-3260 m, the Palaeozoic sequence was described as being dominated by very low-grade (anchimetamorphic) metamorphosed slates. However, the topmost $50 \mathrm{~m}$ of this sequence was described as low-grade (epimetamorphic) metamorphosed phyllites and being different from the underlying anchimetamorphic sandy slates. This macroscopic observation was also supported by thin section descriptions and a marked character change on the resistivity $\log$ at $2882 \mathrm{~m}$ depth (Figure 9). The thin section descriptions of the cores taken in deeper part of the Palaeozoic sequence (cores \#8, 9 and 10), done by Endre BALÁZs, also mention the presence of opaque grains responsible for the dark grey colour of the rock. Some of these opaque grains display even fibrous fabric indicating their organic origin. Therefore the report classified these grains as anthracite, or even graphite, with a question mark (Figure 9).

In our assessment, the detailed post-drill analysis of the well and reflection seismic data (Figure 9) proved the predrill interpretation of HORVÁTH \& RUMPLER (1984) assuming the presence of a major Alpine overthrust plane. The
$2882 \mathrm{~m}$ depth picked for the overthrust plane in the Tét-3 well using the well logs corresponds reasonably to the top of the prominent reflector package (Figure 9) in lieau of a proper synthetic seismic tie.

The sub-thrust hydrocarbon exploration play of the Tét3 well failed as it did not penetrate the expected Mesozoic reservoir sequence beneath the detachment surface, but it has rather found non-reservoir, low grade Palaeozoic metamorphics (Figure 9).

The KH-2 seismic profile is another illustration for the frequent coincidence of strong intra-basement reflector packages with the high conductivity layer (Figure 10). This seismic profile was also utilised by NÉMETH (2014) and she projected 17 of the 1D MT inversion results from the nearby KA-3 MT transect. Compared to the seismic example discussed above (Figure 8), there are two prominent reflector bundles on this profile which appear to correlate very well with the very low resistivity rock units (i.e. 0.36 and $4.67 \Omega \mathrm{m})$ defining the TCA along this transect. Note that there are at least two of these MT anomalies on top of each other, a shallower one and a deeper one, corresponding to two interpreted Eoalpine detachment levels (Figure 5).

\section{Interpretation of the data in terms of an Alpine graphite-bearing detachment level}

In the overall framework of the Eastern Alps, the outcropping Greywacke Zone at the base of the Northern Calcareous Alps (Figure 1) is a very good analogue for the subsurface structural fabric beneath the Hungarian NW Pannonian Basin (Figure 3). In particular, historically

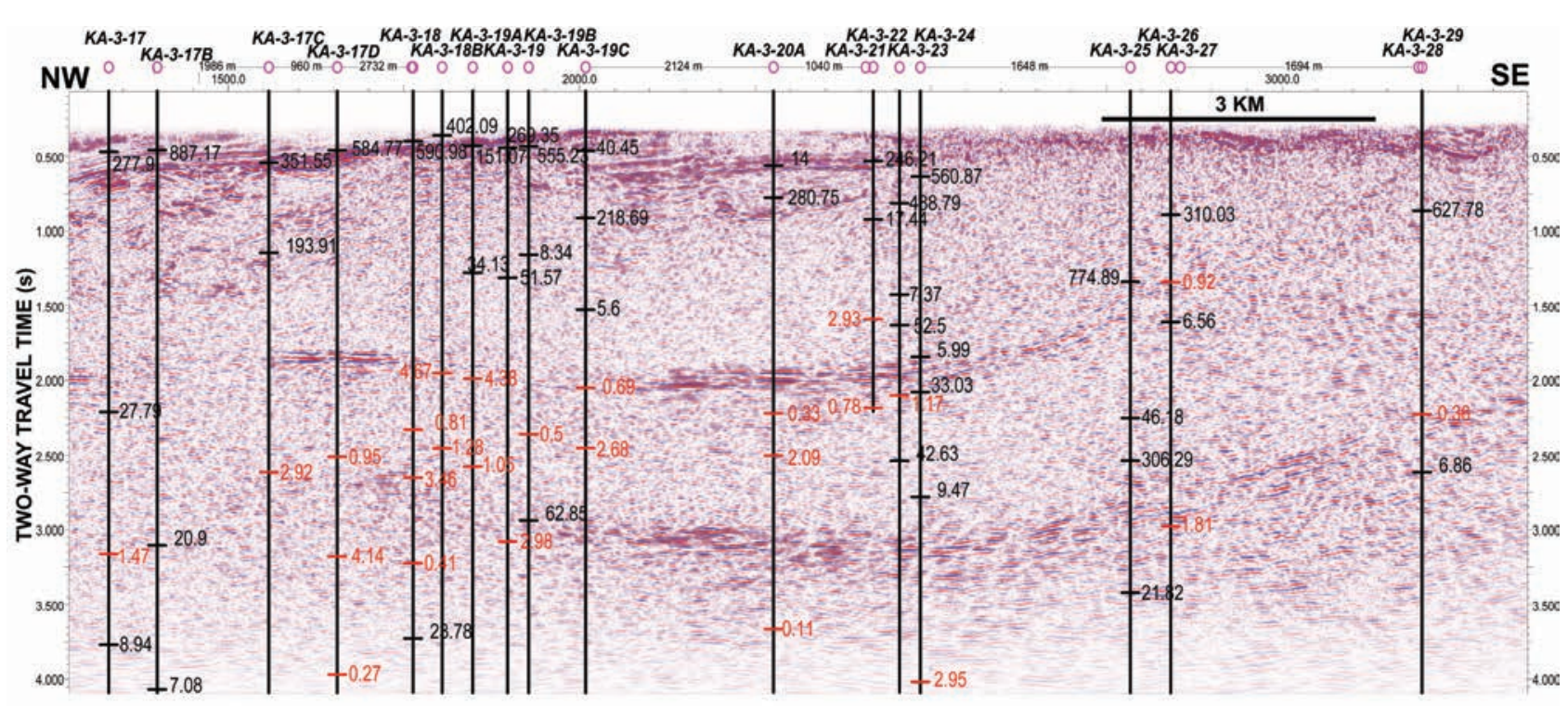

Figure 10. Vintage industry 2D reflection seismic data (Line KH-2) in north-western Hungary showing the presence of Cretaceous Alpine nappe contacts as subhorizontal bright reflector packages in the pre-Cenozoic basement of the Pannonian Basin. Resistivity values based on MT soundings are shown to illustrate the good match of the high-conductivity MT anomaly (TCA) with the inferred Alpine overthrust plane (for location see Figure 4)

10. ábra. Az Északnyugat-Magyarország területén található $2 D$ szeizmikus reflexiós szelvényeken a kréta korú, alpi takaróhatárok közel vizszintes helyzetü erös reflektorokként jelentkeznek a prekainozoos aljzatban. Az MT szondázáson alapuló ellenállásértékek jó egyezést mutatnak a magas vezetöképességü MT anomália (TCA) és az alpi takaróhatárok helyzete között (a szelvény nyomvonalát lásd a 4. ábrán) 


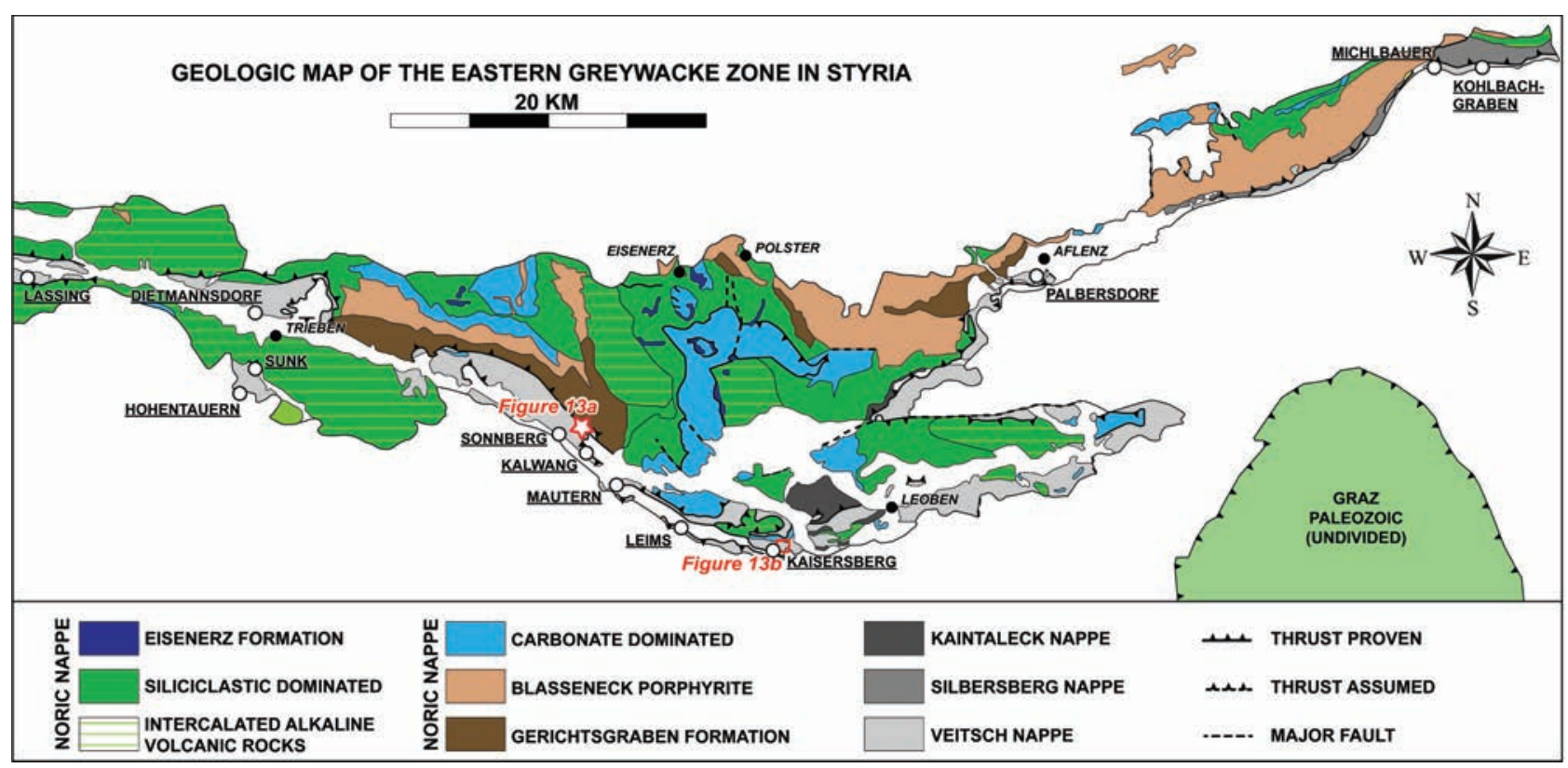

Figure 11. Geologic map of the eastern Greywacke Zone in Styria (GASSER et al. 2009) with the location of our own samples (listed in Table I) and those of RANTITSCH et al. (2004). For location of this area within the Eastern Alps, see Figure 1

11. ábra. A stájerországi keleti Grauwacke-zóna geológiai térképe (GASSER et al. 2009). A RANTITSCH et al. (2004) által megvizsgált pontokat aláhuzással jeleztük. A mi mintáinkat illetöen a kibúvás (13. ábra, a) helyét a térképen piros csillag, a kaiserbergi területet (13. ábra, b) pedig a piros négyzet jelöli. A Grauwacke-zóna elhelyezkedése a Keleti-Alpokon belül az 1. ábrán látható

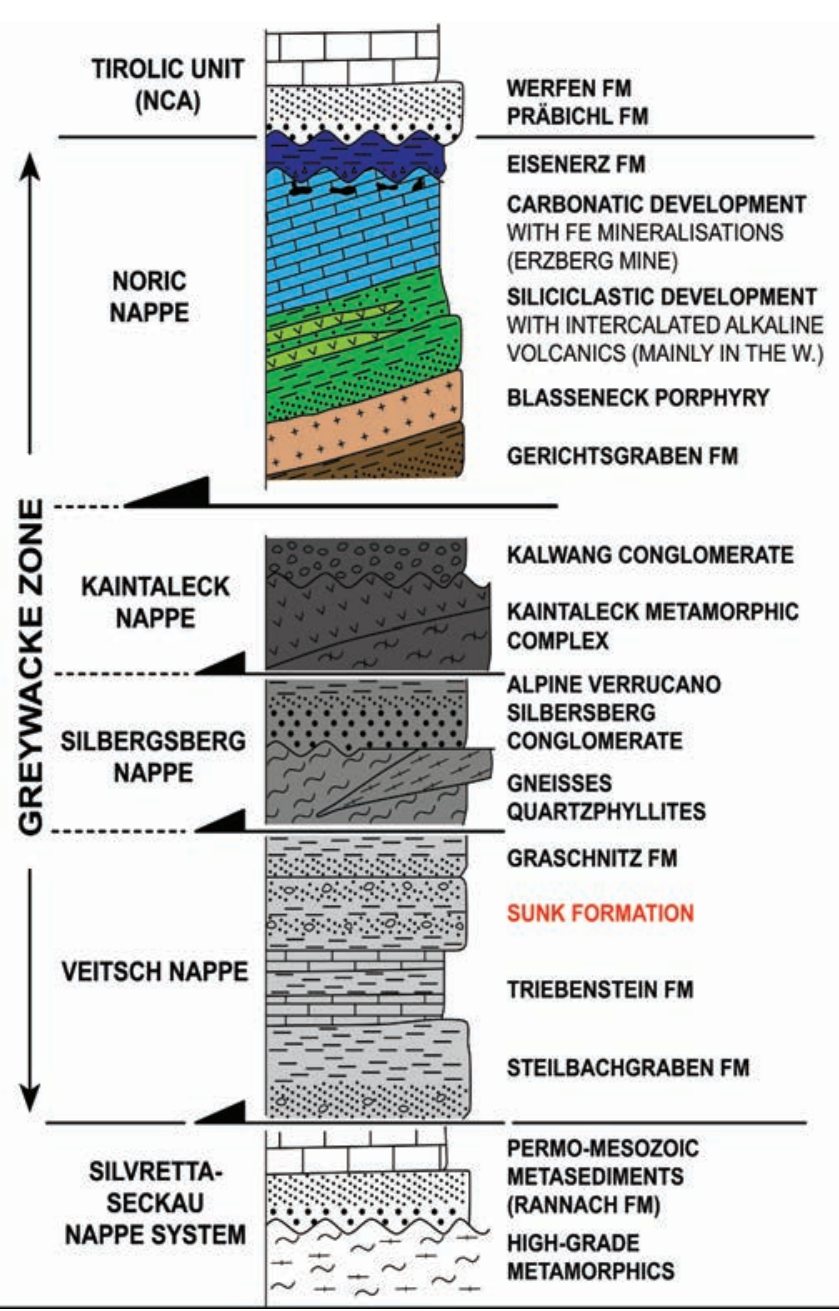

numerous graphite occurrences were described in the Eastern Greywacke Zone (Figure 11) and many of these were mined in Styria (e.g. Metz 1938, Scharfe 1981, AignER et al. 1990, RANTITSCH et al. 2004). We acknowledge the presence of graphite in the Gurktal Nappe complex (e.g. FlüGEl \& NEUBAUER 1984, KorOKNAI et al. 1999) and in the Drauzug-Gailtal area as well (e.g. ÁdÁm et al. 1990). However, for our physical measurements of the conductivity we needed a reference area with massive graphite (Figure 11 and Table I) and that is why we chose the eastern Greywacke Zone as the best analogue area in the Eastern Alps.

The Greywacke Zone has a very complex internal structure (Figures 11 and 12), as it has several Eoalpine nappe units in it (e.g. NeUBAUER et al. 1994). These four major Alpine thrust sheets were subdivided by their basement lithologies, their Late Palaeozoic to Triassic cover sequences, and the degree of pre-Alpine metamorphism. These are, from footwall

Figure 12. In the Greywacke Zone of the Austroalpine nappe stack there are several nappe units (e.g. NeuBAUER et al. 1994). In particular, the Carboniferous Sunk-formation (up to $150 \mathrm{~m}$ thick) of the Veitsch nappe unit is interpreted as a deposit formed in a delta environment with coal seams in it, presently exposed on the surface in a greenschist metamorphosed facies. The age of Alpine greenschist facies metamorphic overprint: 100-80 Ma (Eoalpine, i.e. Late Cretaceous). Due to this metamorphic imprint, the coals turned to graphite at many locations along the Greywacke Zone in Styria. We adopted the figure from GASSER et al. (2009)

12. ábra. A Grauwacke-zóna számos takarós egységböl épül fel (pl. NEUBAUER et al. 1994). A Veitsch takarós egységen belül található karbon korú Sunk Formáció (akár $150 \mathrm{~m}$ vastagságú) egy deltakörnyezetben lerakódott üledékes rétegsor, benne szénrétegekkel. A formáció zöldpala fáciesként bukkan a felszínre, amely egy 80-100 millió évvel (eoalpi, késó-kréta) ezelótti metamorfózis nyomait örzi. A metamorfózis hatására a szenes rétegek számos helyen grafittá alakultak a Grauwacke-zónában, Stájerországban. Az ábrát készittette GASSER et al. (2009) 
to hangingwall: the Veitsch, Silbersberg, Kaintaleck and Noric nappes. Among these nappes, it is the Veitsch nappe (RATSCHBACHER 1984, 1987), which has the graphite-bearing Carboniferous (Westphalian?) Sunk Formation (up to $150 \mathrm{~m}$ thick). This formation was interpreted as a molasse-like deposit formed in a delta environment with coal seams in it (KRAINER 1992). However, it is presently exposed on the surface in a greenschist metamorphosed facies.

The very well studied age of the Alpine metamorphic overprint for the Sunk Formation ranges between 100-80 Ma (i.e. Late Cretaceous, see RANTITSCH et al. 2004, for a detailed summary). Due to this metamorphism, the coals turned to graphite at many locations along the Greywacke Zone in Styria (Figure 11).

The amount of graphite within the Sunk Formation varies considerably both horizontally and vertically (e.g. RATSCHBACHER 1984, 1987). A typical outcrop of the black schists in this formation may not have more than $5 \%$ graphite in it (Figure 13, a).

Besides the many historic and abandoned graphite mines in Styria, one of the still active mines is located near Kaisersberg (Figure 11). Whereas the earlier graphite mining occurred mostly on the surface, the current mine is a subsurface one, producing very high quality graphite (Figure $13, b$ ). The thickness of the pure graphite deposits is rapidly changing in the area but, based on observations in the active mine, individual graphite seams could reach the $5 \mathrm{~m}$ thickness. Note that just a few metres thick graphite layer could produce the subsurface MT anomaly of the TCA (Figure 6). The true stratigraphic thickness of the entire Sunk Formation is estimated at Kaiserbergs as $200 \mathrm{~m}$, but the apparent thickness is at least twice as thick due to Alpine thrusting.

NeUBAUER et al. (1994) made the critical observation in the Greywacke Zone that in the northern segments of the nappes in the Northern Calcareous Alps the basal, i.e. mostly Palaeozoic stratigraphic portions are missing, suggesting preservation within the other three nappes. This could be explained by the gradual ramping up along the overall NW
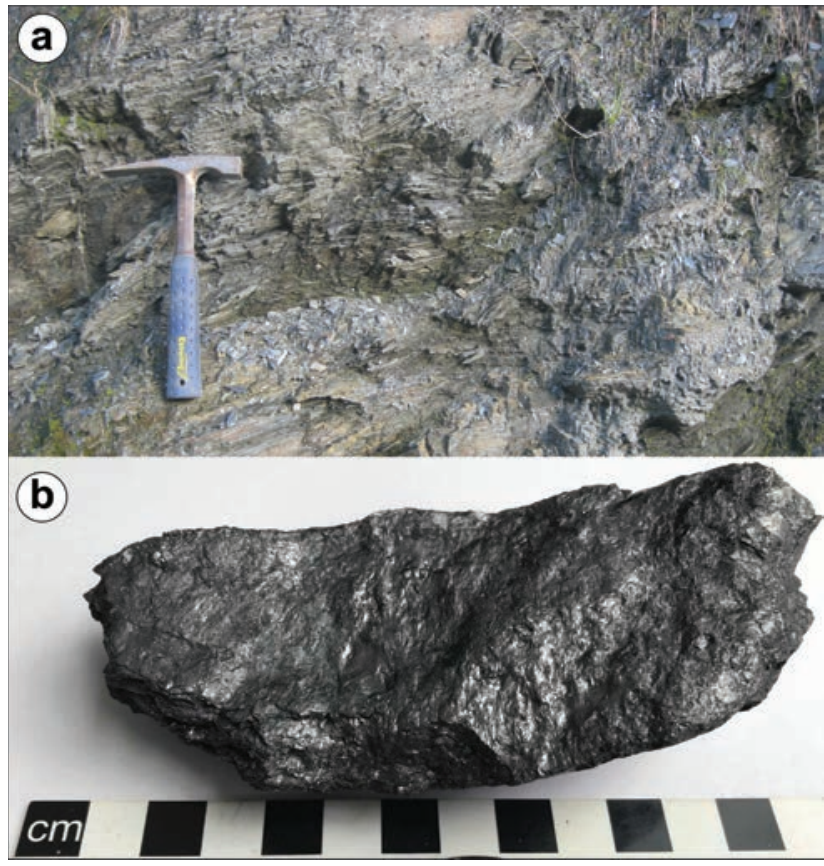

Figure 13. a) Typical outcrop expression of black schists with some graphite content just north of Kalwang, Eastern Alps, Styria, Austria. Location: latitude: $47^{\circ} 26^{\prime} 2.43^{\prime \prime N}$, longitude: $14^{\circ} 45^{\prime} 16.35^{\prime}$ E. b) Pure graphite sample from the Kaisersberg mine, Styria, Austria, courtesy of Prof. RanTiTsch, Leoben University

13. ábra. a) Fillitek jellegzetes felszíni kibukkanása kevés grafittartalommal a Keleti-Alpokban, Kalwangtól északra (Stájerország, Ausztria). A kibukkanás koordinátái: szélesség 47²6’2.43" É, hosszúság 1445'16.35" K. b) Grafitminta a kaisersbergi bányából (Stájerország, Ausztria), prof. RANTITSCH (Leobeni Egyetem) jóvoltából

oriented overthrust surfaces (Figure 14). Thus the prethrusting arrangement of the Permian and Triassic sequences from present NW to SE is as follows: Middle Austroalpine unit, Veitsch nappe, Silbersberg nappe, Kaintaleck nappe and Noric nappe as well as other nappes of the Northern Calcareous Alps. Note the presence of coals in a Carboniferous graben which were caught up and meta-

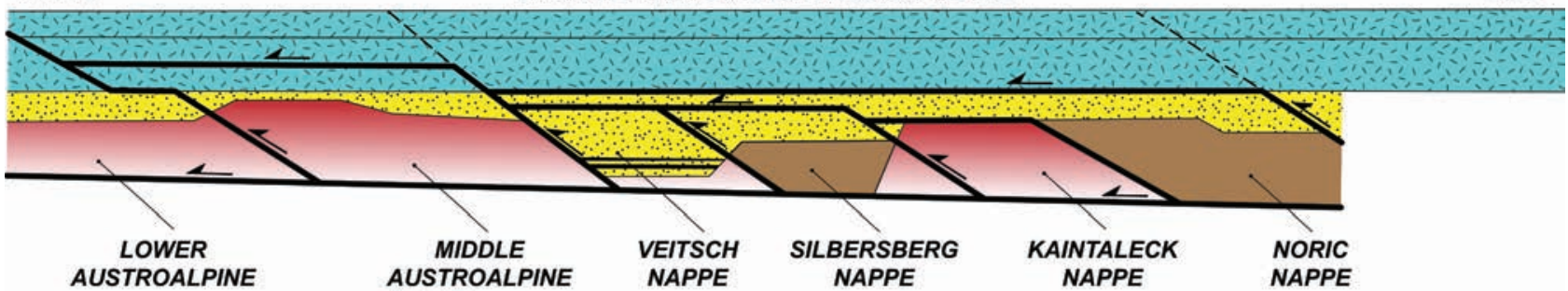

AUSTROALPINE

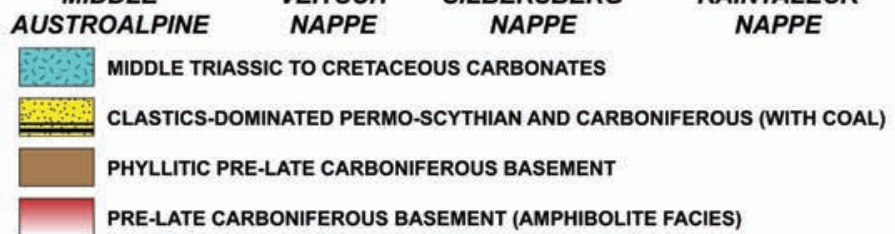

Figure 14. Cartoonish depiction of the pre-thrusting geometry of the Greywacke nappes (NEUBAUER et al. 1994). Note the presence of coals in a Carboniferous graben which were caught up and metamorphosed in the Veitsch nappe during the Cretaceous nappe stacking

14. ábra. NEUBAUER et al. (1994) modellje a Keleti-Alpokban található Grauwacke-zóna különbözö egységeinek takaróképzödés elötti geometriájáról. A vastag, törmelékes közetek által dominált karbon-permoszkíta medencekitöltésböl (sárga színnel) alakult ki a kréta folyamán a Veitsch takaró egység 
morphosed in the Veitsch nappe during the Cretaceous nappe stacking (NEUBAUER et al. 1994). The corollary of this model that if graphite is indeed the cause of the TCA then it provides clues for the large-scale Carboniferous palaeogeography of the Eastern Alps and the Transdanubian Range (Figure 1). More specifically, using the model of LINZER \& TARI (2010), the nappe systems of the Greywacke Zone and the Transdanubian Range were much closer during the Cretaceous nappe stacking than today. Therefore, the TCA is probably caused by graphite, as metamorphosed Carboniferous coals, beneath the NW Pannonian Basin in a poorly understood and mapped subsurface nappe unit which may be a lateral equivalent of the Veitsch nappe (Figure 12).

\section{Discussion and planned future work}

Graphite is a well-known "fault lubricant" (e.g. ZuLAUF et al. 1990). Rocks rich in graphite have been reported from several major fault zones worldwide (OOHASHI et al. 2011, 2013). Typically, these fault zones are characterised by blackish fault gouge, composed of finely crushed quartzofeldspathic fragments, highly crystallised graphite, and minor accessory clay minerals. Although the amount of graphite fraction varies with the fault zone, most blackish fault gouges contain about 2-12 wt \% of graphite in the bulk fault gouge (e.g. ManatsChal 1999). Furthermore, it has been experimentally proven that even a small fraction of graphite can have a disproportionally large effect on frictional strength where graphite is concentrated by smearing into interlinked layers (e.g. RUTTER et al. 2013).

Whereas we believe that the presence of graphite is the best possible explanation for the TCA, we do not necessarily claim that the graphite is exclusively distributed along the Alpine overthrust planes.

Rather, graphite being present in tectonically thinned nappe units is supported by two observations.

Firstly, the seismic signature of the MT anomaly associated with the TCA is typically not a singular reflector but rather a package of reflectors, corresponding to a few hundred metres thick layer, not to a single interface. Secondly, in many cases the TCA does not have any seismic expression which could mean that the graphite is present in a nappe unit but is not associated with the physical plane of overthrusting.

In order to further refine the model suggested here, we plan to build synthetic 2D seismic reflections sections using the well-constrained Greywacke Zone nappe stack as an input. We also intend to interpret a modern $3 \mathrm{D}$ reflection seismic data set in the vicinity of the critical Tét-3 well (Figure 9).

Also, since we believe that the Greywacke Zone is a closer and more appropriate analogue for the TCA than the DrauzugGailtal area (Figure 1) studied by ÁDÁm et al. (1990), the area around Kaisersberg should be targeted by MT soundings. As the graphite-bearing (Figure 11) Veitsch nappe projects beneath the Northern Calcareous Alps to the north (Figure 1), and certainly ends up in a few kilometres depth, it should provide a very similar MT signal to that of the TCA.

\section{Conclusions}

The exceptionally low resistivity (i.e. $1-2 \Omega m$ ) Transdanubian Conductivity Anomaly (TCA) of the Hungarian part of the NW Pannonian Basin has a very large areal extent (on the order a few thousand square $\mathrm{km}$ ) and it is a subsurface anomaly with no outcrop.

Our results show a very strong spatial correlation between the TCA and the inferred subsurface extent of the Palaeozoic base of the Upper Austroalpine-Transdanubian Range nappe system. Moreover, we found good correlation between the spatial position of the TCA and pronounced seismic reflector packages interpreted to be sub-horizontal Cretaceous Alpine nappe surfaces. Moreover, for the first time, we obtained a reasonable match between an Alpine overthrust plane, marked by a prominent reflector package, a graphite bearing Palaeozoic unit penetrated in a hydrocarbon exploration well and a corresponding MT anomaly. This finding, after 35 years, confirms the pioneering interpretation of HORVÁth \& RUMPLER (1984).

The best explanation for the observed extent and geometry of the TCA is the presence of Carboniferous graphite in sub-horizontal, tectonically thinned (on the order of hundreds of metres) nappe units at the base of the Upper Austroalpine nappe edifice of NW Hungary. Based on our measurements and modelling results, the graphite in the Veitsch Nappe of the Greywacke Zone in the Eastern Alps is considered as the best outcropping analogue for the exceptionally high conductivity rock type responsible for the TCA.

\section{Acknowledgements}

We dedicate this work to the loving memory of Ferenc (Frank) HoRvÁTH (1936-2018). He was much more than an inspiration to us, being not only an exceptional scientist, but also a great teacher, a friend and a philosopher.This paper is largely based on the MSc thesis of one of the co-authors (Viktória NÉMETH), supervised by Prof. HoRváth at the ELTE Geophysical Department in 2014.

Prof. RANTitsch and Prof. SAChSEnhofer of Leoben University, kindly provided several graphite samples from various locations in the Eastern Alps and the Bohemian Massif of Austria. Imre ERKI kindly measured the electric conductivity most of these graphite samples. Arnold ORANGE of AOA Geohysics provided very useful feedback on an early draft of this paper based on his longstanding experience with magnetotelluric prospecting. Constructive and positive comments by Prof. Stefan SCHMID are gratefully acknowledged although our geological understanding of the Alpine subsurface between the Eastern Alps and the Pannonian Basin is somewhat different. Much less helpful comments by an anonymous reviewer are noted. We also very much appreciate the editorial efforts of Orsolya SZTANÓ. 


\section{References - Irodalom}

ÁDÁM., A. 1976: Distribution of the electrical conductivity in seismic (deep) fractures in Transdanubia. — Acta Geodaetica, Geophysica et Montanistica Hungarica11, 277-285.

ÁdÁM, A. 1987: Tectonic effects in the magnetotelluric field and their numerical modelling. — Gerlands Beitrage zur Geophysik 96, 17-31.

ÁdÁm, A. 1996: Regional magnetotelluric (MT) anisotropy in the Pannonian Basin (Hungary). — Acta Geodaetica, Geophysica et Montanistica Hungarica 31, 191-216.

ÁDÁM, A. 2001: Relation of the graphite and fluid bearing conducting dikes to the tectonics and seismicity (Review on the Transdanubian crustal conductivity anomaly). — Earth Planets Space 53, 903-918. https://doi.org/10.1186/bf03351687

ÁDÁM, A. \& VERŐ, J. 1965: Über die ursachen der Erdstromverteilung in Ungarn mit besonderer Berücksichtigung der Geologie des Landes. - Freiberger Forschungshefte Reihe C, $174 \mathrm{p}$.

ÁdÁm, A., Horváth, F. \& Stegena, L. 1970: Investigation of plate tectonics by magnetotelluric anistropy. — Annales Universitatis Scientiarum Budapestinensis de Rolando Eötvös Nominatae - sectio Geologica 14, 209-218.

ÁdÁM, A., Duma, G. \& Horváth, J. 1990: A new approach to the electrical conductivity anomalies in the Drauzug-Bakony geological unit. — Physics of the Earth and Planetary Interiors 60, 150-162. https://doi.org/10.1016/0031-9201(90)90258-y

Aigner, H., Gratzer, R. \& SCHMid, Ch. 1990: Graphit-Prospektion Lärchkogel bei Hohentauern und Teichengraben bei Kalwang. Mitteilungen der Abteilung für Geologie Paläontologie Landesmuseum Joanneum 48, 47-61.

BALÁZs, E. 1971: Altpaläozoische Gesteine des Beckenuntergrundes der Kleinen Ungarischen Tiefebene.-_Annual Report of Hungarian Geological Institute 1969, 659-673. (In Hungarian with German summary)

BALÁzs, E. 1975: Paleozoic formations of the basement of the Little Hungarian Plain. — Földtani Kutatás 18, 17-25. (In Hungarian).

Bostick, F. X. 1977: A simple almost exact method of magnetotelluric analysis. — In: WARD, S. (ed.): Workshop of Electrical Methods in Geothermal Exploration. University of Utah Res. Institute of U. S. Geologcal Survey Contract 14-08-0001-g-359.

CAGNIARD, L. 1953: Basic theory of the magneto-telluric method of geophysical prospecting. — Geophysics 50, 605-635. https://doi.org/ $10.1190 / 1.1437915$

Constable, S. C., PARKer, R. L. \& Constable, C. G. 1987: Occam's inversion: A practical algorithm for generating smooth models from electromagnetic sounding data. — Geophysics 52, 289-300. https://doi.org/10.1190/1.1442303

FlÜGEL, H. W. \& NeUbaueR, F. 1984: Steiermark: Erläuterungen zur geologischen Karte der Steiermark, 1: 200.000. — Geologische Bundesanstalt $127 \mathrm{p}$.

Froitzheim, N., PlasienKa, D. \& Schuster, R. 2008: Alpine tectonics of the Alps and Western Carpathians. - In: McCAnN, T. (ed.): The Geology of Central Europe. Volume 2: Mesozoic and Cenozoic. Geological Society, London, 1141-1232. https://doi.org/10.1144/cev2p.6

Gasser, D., Gusterhuber, J. Krische, O., Puhr, B., Scheucher, L., Wagner, T. \& StüWe, K. 2009: Geology of Styria: an overview. Mitteilungen des Naturwissenschaftlichen Vereines für Steiermark 139, 5-36.

Glover, P. W. \& ÁDÁM, A. 2008: Correlation between crustal high conductivity zones and seismic activity and therole of carbon during shear deformation. - Journal of Geophysical Research 113, B12210. https://doi.org/10.1029/2008jb005804

HaAs J., Budai T., Csontos L., Fodor L. \& KonRád Gy. 2010: Magyarország pre-kainozoos földtani térképe, 1:500 000. — Geological Institute of Hungary, Budapest.

HoRVÁth, F. 1993: Towards a mechanical model for the evolution of the Pannonian Basin. — Tectonophysics 226, 333-357. https://doi.org/ 10.1016/0040-1951(93)90126-5

Horváth, F. \& DombRÁDI, E. 2010: Evolution of Hungarian tectonics: An overview of a century of research on and around lake Balaton. - Földtani Közlöny 140, 335-354.

Horváth, F. \& RUMPLER, J. 1984: The Pannonian Basement: extension and subsidence of an Alpine orogene. — Acta Geologica Hungarica 27, 229-235.

Horváth, F., ÁdÁm, A. \& StAnley, W. S. 1987: New geophysical data: evidence for the allochthony of the Transdanubian Central Range. - Rendiconti della Societa Geologica Italiana 9, 123-130.

Horváth, F., Bada, G., Szafián, P., TARi, G., ÁdÁM, A. \& Cloetingh, S. 2006: Formation and deformation of the Pannonian basin: constraints from observational data. - In: GeE, D. \& STEPHENSON, R. (eds.): European Lithospheric Dynamics. Geological Society of London Memoirs 32, 191-206. https://doi.org/10.1144/gsl.mem.2006.032.01.11

KÁZMÉR, M. \& KovÁCS, S. 1985: Permian-Paleogene paleogeography along the eastern part of the Insubric-Periadriatic lineament system: Evidence for continental escape of the Bakony-Drauzug unit. - Acta Geologica Hungarica 28, 71-84.

Keller, G. V. 1987: Rock and Mineral Properties. - Electromagnetic Methods in Applied Geophysics. 1. Theory. - Society of Exploration Geophysicists, Tulsa, Oklahoma.

Kilényi, E., Sefara, J., Kröll, A., Steinhauser, P., Weber, F., Obernauer, D., Pospisil, L., Sutora, A., Rumpler, J. \& Szabó, Z. 1989: Pre-tertiary basement contour map of the Carpatian Basin beneath Austria, Chechoslovakia and Hungary. 1:500 000. — Eötvös Loránd Geophysical Institute of Hungary.

Koroknai, B., Neubauer, F., Genser, J. \& Topa, D. 1999: Metamorphic and tectonic evolution of Austroalpine Units at the western margin of the Gurktal nappe complex, Eastern Alps. - Schweizerische Mineralogische Petrographische Mitteilungen 79, $277-295$.

KraINER, K. 1992: Fazies, Sedimentationsprozesse und Paläogeographieim Karbon der Ost- und Südalpen. — Jahrbuch der Geologishen Bundesanstalt 135, 99-193.

Kuhlemann, J., DunkL, I., BRÜGEl, A., SPIEgEl, C. \& Frisch, W. 2006: From source terrains of the Eastern Alps to the Molasse Basin: Detrital record of non-steady-state exhumation. - Tectonophysics 413, 301-316.

LinZER, H. G. \& TARI, G. 2012: Structural correlation between the Northern Calcareous Alps (Austria) and the Transdanubian Central Range (Hungary). — American Association of Petroleum Geologists Memoir 100, 249-266. https://doi.org/10.1306/ 13351556m1003533 
Nemesi, L., Hobot, J., Kovácsvölgyi, S., Milánkovich, A., PÁPA, A., Stomfai, R. \& VARGA, G. 1994: A kisalföldi medence aljzatának és kéregszerkezetének kutatása az ELGI-ben 1982-90 között. — Geophysical Transactions 38, 193-223.

MetZ, K. 1938: Die Geologie der Grauwackenzone von Leoben bis Mautern. — Jahrbuch der Geologishen Bundesanstalt 88, $165-193$.

MANATSCHAL, G. 1999: Fluid-and reaction-assisted low-angle normal faulting: evidence from rift-related brittle fault rocks in the Alps (Err Nappe, eastern Switzerland). — Journal of Structural Geology 21, 777-793.

NÉMETH, V. 2014: A dunántúli nagy vezetőképességú anomália újraértelmezése. — MSc thesis, Diplomamunka, ELTE TTK, Budapest, 87 p.

NÉMETH, V., Horváth, F., TARI, G. \& WeSZTERGOM, V. 2014: New explanation of an old magnetotelluric observation: source rock of the Transdanubian Range Conductivity Anomaly ascertained. — In: EGU General Assembly Conference Abstracts 16.

Neubauer, F., Handler, R., Hermann, S. \& Paulus, G. 1994: Revised lithostratigraphy and structure of the Eastern Graywacke Zone. Mitteilungen der Österreichischen Geologischen Gesellschaft 86, 61-74.

OоHAshi, K., Hiros, T. \& Sнiмamoto, T. 2011. Shear-induced graphitization of carbonaceous materials during seismic fault motion: experiments and possible implications for fault mechanics. - Journal of Structural Geolology 33, 1122-1134. https://doi.org/ 10.1016/j.jsg.2011.01.007

Oohashi, K., Hirose, T. \& Shimamoto, T. 2013. Graphite as a lubricating agent in fault zones: An insight from low-to high-velocity friction experiments on a mixed graphite-quartz gouge. - Journal of Geophysical Research: Solid Earth 118, $2067-2084$. https://doi.org/10.1002/jgrb.50175

Rantitsch, G., Grogger, W., Teichert, C., Ebner, F., Hofer, C., Mauer, E. M., Schaffer, B. \& Toth, M. 2004: Conversion of carbonaceous material to graphite within the Greywacke Zone of the Eastern Alps. — International Journal of Earth Sciences (Geologische Rundschau) 93, 959-973. https://doi.org/10.1007/s00531-004-0436-1

RATSCHBACHER, L. 1984: Beitrag zur Neugliederung der Veitscher Decke (Grauwackenzone) in ihrem Westabschnitt (Obersteiermark, Österreich. _ Jahrbuch der Geologishen Bundesanstalt 127, 423-453.

RATSCHBACHER, L. 1987: Stratigraphy, tectonics and paleogeography of the Veitsch nappe/Graywackezone, Eastern Alps, Austria: A rearrangement. - Mineralia Slovaca, Monogr., 1987, 407-414.

Rutter, E. H., Hackston, A. J., Yeatman, E., Brodie, K. H., Mecklenburgh, J. \& May, S. E. 2013: Reduction of friction on geological faults by weak-phase smearing. — Journal of Structural Geolology 51, 52-60. https://doi.org/10.1016/j.jsg.2013.03.008

SCHARfe, G. P. 1981: Steirische Graphitvorkommen. — Mitteilungen der Abteilung für Geologie Paläontologie Landesmuseum Joanneum 42, 117-122.

Schmid, S. M., FÜGEnschuh, B., KIssLing, E. \& Schuster, R. 2004: Tectonic map and overall architecture of the Alpine orogen. Eclogae Geologicae Helvetiae 97, 93-117. https://doi.org/10.1007/s00015-004-1113-x

Schmid, S. M., Bernoulli, D. Fügenschuh, B., Matenco, L. Schefer, S. Schuster, R., Tischler, M. \& Ustaszewski, K. 2008: The Alpine-Carpathian-Dinaridic orogenic system: correlation and evolution of tectonic units. - Swiss Journal of Geosciences 101, 139-183. https://doi.org/10.1007/s00015-008-1247-3

Stegena, L., HoRVÁth, F. \& ÁDÁM, A. 1971: Spreading tectonics investigated by magnetotelluric anisotropy. — Nature 231, $442-443$. https://doi.org/10.1038/231442a0

Stegena, L., Horváth, F. \& ÁdÁm, A. 1972: Spreading tectonics investigated by magnetotelluric anisotropy-Reply. — Nature Physics Science 235, p. 121.

TAKÁCS, E. 1968: Anomalous conductivity of the upper crust in the NW foreground of the Bakony Mountains. - Acta Geodaetica, Geophysica et Montanistica Hungarica 3,1-2.

TARI, G. 1994: Alpine Tectonics of the Pannonian Basin. — PhD thesis, Rice University, Houston, 501 p.

TARI, G. 1996: Neoalpine tectonics of the Danube Basin (NW Pannonian Basin, Hungary). — In: Ziegler, P. \& Horváth, F. (eds): PeriTethys Memoir 2: Structure and Prospects of Alpine Basins and Forelands. Mémoires du Muséum national d'historie naturelle 170, 439-454.

TARI, G. \& HorvÁth, F. 2006: Alpine evolution and hydrocarbon geology of the Pannonian Basin: an overview. — In: GolonKA, J. \& PICHA, F. (eds): The Carpathians and their Foreland: Geology and Hydrocarbon Resources. AAPG Memoir 84, 605-618. https://doi.org/10.1306/985733M843141

TARI G. \& HoRVÁTH F. 2010: A dunántúli-középhegység helyzete és eoalpi fejlődéstörténete a Keleti-Alpok takarós rendszerében: egy másfél évtizedes tektonikai modell időszerûsége. — Földtani Közlöny 140, 483-510.

Zulauf, G., KleinSchmidT, G. \& OnCKEn, O. 1990: Brittle deformation and graphitic cataclasites in the pilot research well KTB-VB (Oberpfalz, FRG) — Geological Society, London, Special Publications 54, 97-103. https://doi.org/10.1144/gsl.sp.1990.054.01.10

Manuscript recieved: 13/05/2019 